\section{A Structural Equation Model (SEM) of Governing Factors Influencing the Implementation of t-Government}

\section{Sameer Alshetewi}

School of Computer Science, Engineering and Mathematics, Flinders University, Adelaide, Australia

*Corresponding author: Alshetewi S, School of Computer Science, Engineering and Mathematics, Flinders University, Adelaide, Australia, Tel: +61 8 8201 3911; Email: alshetewi@hotmail.com

Received date: October 15, 2015, Accepted date: January 20, 2016, Published date: January 25, 2016

Copyright: @ 2016 Alshetewi S. This is an open-access article distributed under the terms of the Creative Commons Attribution License, which permits unrestricted use, distribution, and reproduction in any medium, provided the original author and source are credited.

\begin{abstract}
Governments around the world have invested significant sums of money on Information and Communication Technology (ICT) to improve the efficiency and effectiveness of services being provided to their citizens. However, they have not achieved the desired results because of the lack of interoperability between different government entities. Therefore, many governments have started shifting away from the original concept of e-Government towards a much more transformational approach that encompasses the entire relationship between different government departments and users of public services, which can be termed as transformational government (tGovernment). In this paper a model is proposed for governing factors that impact the implementation of tGovernment such as strategy, leadership, stakeholders, citizen centricity and funding in context of Saudi Arabia. Five constructs are hypothesised to be related to implementation of t-Government. To clarify the relationships among these constructs, a structural equation model (SEM) is utilised to examine the model fit with the five hypotheses. The results show that there are positive and significant relationships among the constructs such as the relationships between strategy and t-Government; the relationships between stakeholders and t-Government; the relationships between leadership and t-Government. This study also showed insignificant relationship between citizens' centricity and $\mathrm{t}$-Government and also insignificant relationship between funding and $\mathrm{t}$-Government.
\end{abstract}

Keywords: t-Government; e-Government; Citizens' centricity

\section{Introduction}

Many nations have put in place e-Government applications to enhance the efficiency of the public sector and streamline government systems to enable creating connections between different government organisations. In order to create further efficiencies it has been recommended that countries move towards a goal of transformational government [1,2]. Nowadays, the concept of a transformational government ( $\mathrm{t}$-Government) needs to be viewed on an international scale. In order to facilitate more centrally-connected and citizencentric-government services, and put the needs of individuals and businesses at the center of online processes, many governments have started shifting away from the original concept of e-Government towards a much more transformational approach that considers the entire relationship between different government departments and users of public services, which can be termed as transformational government ( $\mathrm{t}$ - Government) [3-5]. This paper identifies and analysis the governing factors (strategy, leadership, stakeholders, citizen centric and funding) that influence the implementation of $\mathrm{t}$-Government in Saudi Arabia. The proposed model is empirically tested through an analysis data from 217 surveys from various organisations in Saudi Arabia using Structural Equation Modeling (SEM) technique and utilized AMOS version (22) tools.

The organization of this paper is as follows: Section 2 gives an overview of the governing factors. Section 3 provides the methodology for this study which includes the research model, hypotheses and data collection. Section 4 presents the data analysis and results. Section 5 discusses the results, and Section 6 provides the conclusions of the study.

\section{Background}

There is still insufficient research regarding the critical factors that affect transformational government (t-Government) such as technical, organizational and governing factors [6-8]. This section discusses some of the popular governing factors that have been identified (strategy, leadership, stakeholders, funding and citizens centricity) as affecting tgovernment in more details as follows:

\section{Strategy}

Strategies and Regulations are important in any development of eGovernment, and one of the most important elements involved in the implementation of t-Government [9], as its establishment inevitably requires major changes in strategic direction, and to modes of paradigm thinking $[10,11]$. Thus a comprehensive e-Government strategy becomes a major factor when collaboration between government agencies is necessary to ensure the successful presentation of an online service [10-13]. Appropriate regulations are also important for the successful implementation of t-Government, as the absence of such a regulatory framework is one of the more onerous challenges hindering its effective establishment [14-16]. Strategies and regulations are measured through: the importance of e-Government strategy, strategy's plan, strategy's goal, strategy's vision, and strategy's commitment.

\section{Stakeholders}

A key factor in the implementation of t-Government projects will be stakeholders: their presence within any e-Government initiative is fundamental to the success of its interoperability [17-19]. Governments need to identify their stakeholders are, and what they 
want, to succeed in e-government implementation, and achieve the maturity of e-Government [20]. Rowley [21] argued that the classification of stakeholders are often implicit in categorizations of eGovernment such as (G2G), (G2C), (G2B), and (G2E), or they offered by a number of authors. For example, Heeks [22] classified stakeholders to Non-profits, other agencies, citizens/customers, businesses, communities, government. Orange [23], Burke et al. [24] classified stakeholders to Politicians, staff, public, project managers, design developers, other government agencies. United Nations [25] classified stakeholders to Public administrators, programmers, endusers, politicians. As this study only focuses on (G2G) e-Government categorization, it concern only about internal stakeholder in government organisations. According to Al-Rashidi [26] Internal stakeholders are political stakeholders, organizational stakeholders, and technological stakeholders such as Public administrators (employees), Other government agencies, Politicians, E-Government project managers, Design and IT developers, and naturally, cooperation between these categories of stakeholder is critically important to the successful implementation of $\mathrm{t}$-Government projects [27,28]. Cui et al. [29], Hu considers that cross-agency cooperation has the potential to transform the way that governments work, share information, and deliver services to external and internal clients. According to Ebrahim and Irani [30], implementing interoperability involvers many stakeholders at different government level and coordination between these stakeholders is important. In this study, participating stakeholders are measured by: stakeholder's involvement, stakeholder's management, and stakeholder's coordination.

\section{Leadership}

Leadership always plays a significant role to any group endeavor, and is thus the quality of the leadership employed will have a significant impact on the successful implementation of $\mathrm{t}$-Government, particularly in e-Government projects requiring a high level of interoperability [19,24]. t-Government projects are long-term: consequently the quality of leadership is crucial [31]: strong leaders are required to overcome the inherent challenges involved. Researchers have identified both vision and leadership as the main drivers of successful e-Government $[11,18,32]$, consequently, and according to many studies, [27,33,34], Effective leadership of this kind is a major contributory factor to the successful implementation of $\mathrm{t}$-Government. The effectiveness of any leadership derives from its quality. Altameem and Prybutok [34], Zhang et al. [15] state that effective leaders express more complex and contradictory behaviour than ineffective leaders. Zairi [35] claims that "Nowadays leadership is considered as a must for survival. It comes from the level of inspiration, commitment generated and corporate determination to perform". Thus a particular challenge to government as top manager of a project is the selection of a strong political leader with both IT and management skills capable of leading the project to a successful completion $[11,18,36]$. In this study leadership is measured by: leadership support, leadership style, and the influence of strong leadership.

\section{Citizen centricity}

A citizen centric involves the provision of services from the enduser's point of view rather than the perspective of the government department [36-39]. A t-Government project should have a citizen centric perception. However, citizen-centric service delivery is a complex issue with many perspectives that need to be considered at the very beginning of a transformation project. The provision of citizen- centric service has been identified by some researchers as a critical success factor [38]. Therefore, $t$-Government should be provided in a way that enable citizens to easily access information and complete their transactions. In order to assess the level of success of the provision of citizen centric services end-user satisfaction should be regularly measured [36-39]. Citizens' centricity is measured in this study by: citizen centric legislation, citizen's measurement and citizen's satisfaction.

\section{Funding}

e-Government initiatives being long-term, they require long-term financial support from the Government, which can become a major challenge if that funding has to come from a government where political influence may interfere with decisions taken by high level officials [19,40]. Moreover, Gottipati [41] argues that the way egovernment projects are being reviewed and funded in the Arabian gulf is that such projects appear to seen as budget-based instead of seeing those projects as project-based budgets. Thus funding is inevitably a crucial factor in the implementation of t-Government, as a lack of adequate, consistent financial backing will become a major challenge to the successful implementation of any e-Government project [42]. Adequate funding supports the necessary integration of government organisations by facilitating the development of infrastructure (such as building, technology, human resources) required to implement $\mathrm{t}$-Government, and ensures that goals and targets are met on time. Its impact on e-Government interoperability is also positive [19]. Fund is measured in this study through fund amount, measurement mechanism, fund management, and fund controlling.

\section{Methodology}

\section{Research model}

The objective of this study is to identify governing factors that influence the implementation of t-Government in Saudi Arabia. The research model of the study is presented below in Figure 1. The constructs included in the research model, were drawn from the variables used from a review of the relevant literature Tables 1 and 2.

\begin{tabular}{|c|c|c|}
\hline Constructs & Items & References \\
\hline \multirow{5}{*}{$\begin{array}{l}\text { Strategy \& } \\
\text { Regulations }\end{array}$} & e-Gov strategy & {$[9,43]$} \\
\hline & Commitment & {$[10,44]$} \\
\hline & Plan & {$[10,31]$} \\
\hline & Goal & {$[10,19,28]$} \\
\hline & Vision & [10] \\
\hline \multirow[t]{3}{*}{ Leadership } & Support & {$[10,45-47]$} \\
\hline & Style & {$[11,24,28,31,46,48]$} \\
\hline & Strong leader & {$[28,46,49,50]$} \\
\hline \multirow[t]{4}{*}{ Stakeholders } & Involvement & {$[28,46,51-54]$} \\
\hline & Identification & {$[21,51,52]$} \\
\hline & Management & {$[51,55]$} \\
\hline & Cooperation & {$[11,29,46,51,52]$} \\
\hline
\end{tabular}


Citation: Alshetewi S (2016) A Structural Equation Model (SEM) of Governing Factors Influencing the Implementation of t-Government. J

Page 3 of 7

\begin{tabular}{|l|l|l|}
\hline Fund & Amount & {$[42,43,47,56,57]$} \\
\cline { 2 - 3 } & Measurement mechanism & {$[58]$} \\
\cline { 2 - 3 } & Management & {$[58-60]$} \\
\cline { 2 - 3 } & Controlling & {$[19,58,59]$} \\
\hline
\end{tabular}

Table 1: Governing Factors Influencing t-Government implementation from the Literature.

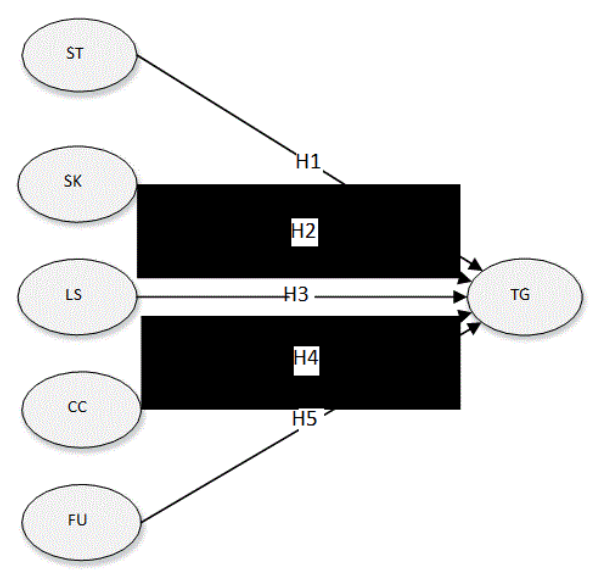

Figure 1: The hypotheses model.

\section{Research hypotheses}

\begin{tabular}{|l|l|}
\hline No & Hypotheses \\
\hline H1 & Strategy positively influence the implementation of t-Government \\
\hline H2 & Stakeholders positively influence the implementation of t-Government \\
\hline H3 & Leadership positively influences the implementation of t-Government \\
\hline H4 & $\begin{array}{l}\text { Citizens Centricity positively influences the implementation of t- } \\
\text { Government }\end{array}$ \\
\hline H5 & Funding positively influences the implementation of t-Government \\
\hline
\end{tabular}

Table 2: Research hypotheses.

\section{Data collection}

This study uses a quantitative research approach with methods that include a survey. The survey was divided into different sections to enable respondents to very understand it and a Likert scale with six levels of possible answers was used (from Strongly Agree to Strongly Disagree). Survey was conducted in Saudi Arabia from December 2013 to April 2014. 1194 survey questionnaires are distributed to 166 organisations. From this 917 people have viewed the survey, and 477 people have responded. From the balance, 258 responses are incomplete (more than $70 \%$ of the questions are unanswered) and hence unusable. The number of completed responses is 217 .

\section{Data Analysis and Result}

Statistical Packages for Social Science (SPSS) version (22) was used to analyse the data collected through the surveys. The study applied the Structural Equation Modelling (SEM) technique and utilized AMOS version (22) tools to test the hypotheses among the variables in the model. Structural equation modelling (SEM) is a statistical technique that allows the researcher to examine multiple interrelated dependence relationships in a single model. SEM is a popular approach in social science research. It is popular analysis technique because it has flexibility for interpreting the theory to be tested and the sample data. The following section will illustrate the analysis of the study in more detail.

\section{Descriptive statistical perspective}

In the questionnaire 5 demographic questions were used to capture demographic information: age, education level, occupation, organisation size, and the number of G2G services. More than (72.9 percent) of the respondents were between 31 and 45 years old and more than ( 88 percent) have hold a Bachelor's or postgraduate degree. More than (41 percent) of the respondents are manager, more than (55 percent) of the respondents come from organisation have more than 500 employee, and (53 percent) of the respondents come from organisation have from (1-5) G2G services. The demographic information about the respondent is summarised in Table 3.

\begin{tabular}{|c|c|c|c|}
\hline \multicolumn{2}{|c|}{ Demographic Variables } & \multirow{2}{*}{$\begin{array}{l}\text { Frequency } \\
7\end{array}$} & \multirow{2}{*}{$\begin{array}{l}\text { Percent \% } \\
3.2\end{array}$} \\
\hline Age group & $20-25$ & & \\
\hline & $26-30$ & 26 & 12.0 \\
\hline & $31-35$ & 52 & 24.0 \\
\hline & $36-40$ & 36 & 16.6 \\
\hline & $41-45$ & 37 & 17.1 \\
\hline & $46-50$ & 25 & 11.5 \\
\hline & $51-55$ & 26 & 12.0 \\
\hline & More than 55 & 8 & 3.7 \\
\hline \multirow[t]{6}{*}{ Education level } & High school & 3 & 1.4 \\
\hline & Diploma & 24 & 11.1 \\
\hline & Bachelor & 87 & 40.1 \\
\hline & High Diploma & 13 & 6.0 \\
\hline & Master & 74 & 34.1 \\
\hline & Doctorate & 16 & 7.4 \\
\hline \multirow[t]{5}{*}{ Occupation } & Manager & 26 & 12.0 \\
\hline & Dept Manager & 64 & 29.5 \\
\hline & System-analysis & 60 & 27.6 \\
\hline & Technician & 13 & 6.0 \\
\hline & Others & 54 & 24.9 \\
\hline \multirow[t]{2}{*}{ Employee number } & Less than 100 & 31 & 14.3 \\
\hline & $101-500$ & 65 & 30.0 \\
\hline
\end{tabular}


Citation: Alshetewi S (2016) A Structural Equation Model (SEM) of Governing Factors Influencing the Implementation of t-Government. J

Page 4 of 7

\begin{tabular}{|l|l|l|l|}
\hline & $501-1000$ & 35 & 16.1 \\
\cline { 2 - 4 } & $1001-2000$ & 25 & 11.5 \\
\cline { 2 - 4 } & $2001-5000$ & 20 & 9.2 \\
\cline { 2 - 4 } & More than 5000 & 41 & 18.9 \\
\hline $\begin{array}{l}\text { Numbers of G2G Gervices } \\
\text { s }\end{array}$ & $1-5$ & 115 & 53 \\
\cline { 2 - 4 } & $6-10$ & 61 & 28.1 \\
\cline { 2 - 4 } & $11-15$ & 5 & 2.30 \\
\cline { 2 - 4 } & $16-20$ & 6 & 2.76 \\
\cline { 2 - 4 } & None & 30 & 13.82 \\
\hline
\end{tabular}

\begin{tabular}{|l|l|l|}
\hline ST & 0.947 & 0.783 \\
\hline CC & 0.824 & 0.621 \\
\hline LS & 0.976 & 0.932 \\
\hline TG & 0.921 & 0.797 \\
\hline FU & 0.927 & 0.762 \\
\hline
\end{tabular}

Table 5: Convergent validity results.

Table 3: The demographic information.

\section{Reliability verification}

This study used Cronbach's alpha to measure the internal consistency [48], outline that internal consistency is a commonly used technique to assess the reliability by using Cronbach's alpha. Also, Black et al. [49], Hair Jr. suggests that the reliability test should be conducted before the construct validity analysis is commenced. Constructs are considered reliable when Cronbach's alpha is 0.70 or higher. As shown in Table 4, all estimated values of the constructs were above the recommended value $(0.70)$ which indicates that there is a strong reliability and high internal consistency in measuring relationships in the model.

\begin{tabular}{|l|l|l|}
\hline Construct & No of Items & Cronbach's Alpha \\
\hline ST & 5 & 0.947 \\
\hline SK & 3 & 0.946 \\
\hline CC & 3 & 0.779 \\
\hline LS & 3 & 0.975 \\
\hline FU & 4 & 0.850 \\
\hline TG & 3 & 0.920 \\
\hline
\end{tabular}

\begin{tabular}{|c|c|c|}
\hline Factors & Items & Estimate \\
\hline \multirow[t]{3}{*}{ SK } & STAK_4 & 0.981 \\
\hline & STAK_2 & 0.897 \\
\hline & STAK_1 & 0.899 \\
\hline \multirow[t]{5}{*}{ ST } & LE_2 & 0.855 \\
\hline & LE_1 & 0.94 \\
\hline & STA_3 & 0.874 \\
\hline & STA_2 & 0.871 \\
\hline & STA_4 & 0.882 \\
\hline \multirow[t]{3}{*}{$\mathrm{CC}$} & C_3 & 0.644 \\
\hline & C_2 & 0.678 \\
\hline & C_1 & 0.992 \\
\hline \multirow[t]{3}{*}{ LS } & L_3 & 0.984 \\
\hline & L_2 & 0.915 \\
\hline & L_1 & 0.996 \\
\hline \multirow[t]{2}{*}{ FU } & F_1 & 0.979 \\
\hline & F_2 & 0.816 \\
\hline
\end{tabular}

Table 6: Constructs factor loading.

Table 4: Cronbach alpha reliability results.

\section{Validity test}

All the constructs were shown to have a composite reliability greater than the threshold level of 0.60 and their Average Variance Extracted (AVE) is also greater than the threshold level of 0.50 as shown in Table 5 . Also, all the indicators (factors) had significant loadings greater than $0.50(p<0.001)$ on their respective constructs as shown in Table 6.

Since their factor loadings were meaningful and highly significant, they were retained in the measurement model. Moreover, Average Variance Extracted (AVE) is greater than the squared correlation of constructs show in Table 7 . These results indicated that the measurement model possessed substantial convergent validity and unidimensionality [49].

\begin{tabular}{|l|l|l|}
\hline & CR & AVE \\
\hline SK & 0.948 & 0.859 \\
\hline
\end{tabular}

\begin{tabular}{|l|l|l|l|l|l|l|}
\hline & SK & ST & CC & LS & TG & FU \\
\hline SK & 0.927 & & & & & \\
\hline ST & 0.511 & 0.885 & & & & \\
\hline CC & 0.175 & 0.11 & 0.788 & & & \\
\hline LS & 0.404 & 0.257 & 0.138 & 0.966 & & \\
\hline TG & 0.26 & 0.025 & 0.033 & 0.247 & 0.893 & \\
\hline FU & 0.045 & 0.012 & 0.168 & -0.061 & 0.053 & 0.873 \\
\hline
\end{tabular}

Table 7: Discriminant validity: Average Variance Extracted (AVE) with squared correlation of construct.

\section{Hypothesis Testing Results}

Testing of hypotheses aims to determine which independent variables provide a statistically meaningful relationship to the dependent variables [49]. This study tested the hypotheses using SEM. 
SEM provides information about the hypothesized impact both directly from one variable to another and via other variables positioned between the other two. This study was conducted using AMOS 22.0.

\begin{tabular}{|l|l|l|l|l|}
\hline Hypotheses & $\begin{array}{l}\text { Path } \\
\text { coefficient }\end{array}$ & C.R. & P value & Result \\
\hline TG<---ST & 0.15 & 2.151 & $0.03^{*}$ & Supported \\
\hline TG<---SK & 0.25 & 3.753 & $* * *$ & Supported \\
\hline TG <---LS & 0.19 & 2.866 & $0.004^{*}$ & Supported \\
\hline TG<---CC & 0.03 & 0.514 & N.S & Not supported \\
\hline TG<---FU & 0.06 & 0.955 & N.S & Not supported \\
\hline${ }^{*} p<0.05 ;{ }^{* *} p<0.01 ;{ }^{* * *} p<0.001$ & \multicolumn{5}{|l}{} \\
\hline
\end{tabular}

Table 8: Hypothesis testing results.

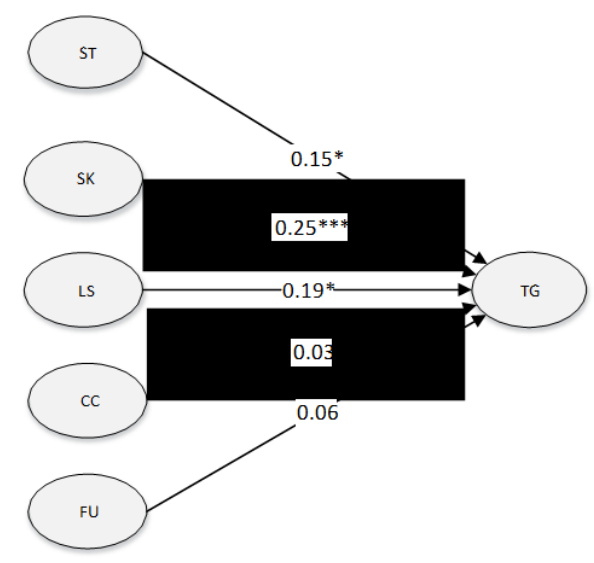

Figure 2: Path coefficients for the proposed structural model.

The statistics of the model based on the SEM output are: RMSEA 0.053, Chi -square/df 1.61, CFI 0.975, TLI 0.971. These values are shown in Figure 2, within the threshold limits prescribed by Black et al. [49], Hair Jr. and Kline [49,50]. Table 8 represents the results of testing the current study hypotheses. The 'Result' column indicates whether that hypothesis was: supported or not supported depending on the result of the $p$ value.

\section{Discussion}

The aim of this study is to test how governing factors namely strategy, stakeholders, leadership, citizens' centricity and funding to the implementation of $\mathrm{t}$-Government among $(\mathrm{n}=217)$ from different organisations in Saudi Arabia. The SEM analysis data supported the analysis and results of the SEM were summarized as follows:

\section{Strategy positively influences the implementation of $t$-Government}

Strategy indicated a significant positive impact on the change towards a t-Government. This hypothesis is supported in not only this study but other studies conducted previously. $[10,11,19,28,43-45,51-53]$ reported the impact of the strategy to the implementation of $\mathrm{t}$-Government. Based on this result, decision- makers, and e-Government officials should pay attention to the eGovernment strategy for the transformation to a $\mathrm{t}$-Government. It should be translated into an effective and clear roadmap that can be easily interpreted and committed to by all government organisations.

\section{Stakeholders positively influence the implementation of $t$ - Government}

This hypothesis is supported in this study and is consistent with previous studies $[19,15,28,54-57]$ found the impact of stakeholders on the implementation of t-Government. Based on this result, it is clearly understandable that decision-makers and e-Government officials should pay attention to the existence of involvement, commitment, management and cooperation of the stakeholders toward the success of the implementation of $\mathrm{t}$-Government.

\section{Leaderships positively influences the implementation of $t$ - Government}

This hypothesis is supported in this study and is consistent with previous studies $[9,10,19,28,58]$. Therefore, decision-makers, and eGovernment officials should pay more attention to leadership support, interaction and cooperation with sufficient knowledge and style on the implementation of t-Government.

Citizens' Centricity positively influences the implementation of $t$ Government

This hypothesis is not supported in this context and is inconsistent with previous studies $[30,36,38,39]$ pointed out the impact of Citizen Centric on the change towards a t-Government. The reason for that could be the lack of regular reviewing and measuring of citizen satisfaction, and participation issues have not been adequately addressed. According to [2], the United Nations e-Government Survey uses a three stage model to assess the e-participation index (EPI). The first stage: 1) e-information measures how participants access public information and information upon demand, 2) e-consultation measures the engagement of contributions of people on public policies and services and 3) e-decision-making to measure the empowerment of people on designing the service delivery. The e -participation index (EPI) indicates Saudi Arabia achieved $85.19 \%$ in stage 1, 27.27\% in stage 2 , and $11.11 \%$ in stage 3 which means there is a gap in citizen centric focus. Therefore, decision-makers, and e-Government officials should pay more attention to citizen satisfaction, service quality and should be regularly measured.

\section{Funding positively influences the implementation of t-Government.}

This hypothesis is not supported in this context, and it is inconsistent with previous studies $[42,43,52,60]$ who pointed out that there is an impact of funding towards t-Government. The reason for that could be the support from the custodian of the two holy mosques King Abdullah to the transformation to e-Government projects. Therefore, funding is not an obstacle by itself the implementation of tGovernment, and more effort should be considered to create plans and strategies to fund e-Government projects and to further monitor this funds.

\section{Conclusion}

The aim of this study is to identify and test empirically the factors that affect implementation of $\mathrm{t}$-Government from multiple perspectives. It provides a model to assess the success factors to the implementation of $\mathrm{t}$-Government in Saudi Arabia. Also, it identifies 
the most important factors in this context, in terms of evaluating the success of the change to t-Government in Saudi Arabia.

Based on the data collected and the results of the analysis, this study showed positive and significant relationships between factors such as the relationships between strategy and t-Government $(\mathrm{H} 1)$; the relationships between stakeholders and t-Government $(\mathrm{H} 2)$; and the relationships between leadership and t-Government (H3). Also, it indicated that there is insignificant relationship between citizens' centricity and t-Government (H4); and insignificant relationship between funding and t-Government (H5).

The results of this study generate some useful implications for decision-makers, and government officials in developing countries in general and especially Saudi Arabia, with important guidelines in understanding how different factors affect the transition to a transformational government. Since the Saudi government and many other governments face the problem of a low level of e-government integration [2], it is hoped that the results this study will support decision-makers, and government officials in increasing the level of success of $\mathrm{t}$-Government.

To summarise, this study has attempted to offer a better understanding of the relevant factors that may influence the change toward $\mathrm{t}$-Government through an analysis of the literature and a survey. This study is based on 217 respondents and due to its limited size and exclusive focus on Saudi Arabia future studies can be conducted in future to verify the results and also tests the factors in other cultural contexts. In addition, future research can expand this study by including the effect of different factors such as organisational and technical factors that may impact the implementation of $t$ Government in Saudi Arabia.

\section{References}

1. Zukang S (2012) E-Government Survey 2012: E-Government for the People. United Nations report.

2. Hongbo W (2014) E-Government Survey 2014: E-Government for the Future we Want. United Nations report.

3. Sundberg HP, Sandberg KW (2006) Towards e-government: A survey of problems in organisational processes. Business Process Management Journal 12: 149-161.

4. Al-Khouri AM (2011) An innovative approach for e-Government transformation.

5. Alshetewi S, Vries D (2013) Organisational, Technological and Governance Factors Influencing T-government. International Journal of Advanced Research in Computer Science \& Technology (IJARCST).

6. Van Veenstra AF (2011) Barriers and impediments to transformational government: insights from literature and practice. Electronic Government, an International Journal 8: 226-241.

7. Marc N, Grace A (2012) Interoperability in the e-Government Context. Carnegie Mellon University, Software Engineering Institute: pp: 1-35.

8. Solli-Saether H, Flak L (2012) Interoperability, maturity and benefits in egovernment.

9. Ray D (2011) A critical survey of selected government interoperability frameworks. Transforming Government: People, Process and Policy 5: 114-142.

10. Lam W (2005) Barriers to e-government integration. Journal of Enterprise information Management 18: 511-530.

11. Elnaghi M (2009) Instigating Transformational Government at a Municipality Level: A Case Study. Handbook of Research on ICT-Enabled Transformational Government: A Global Perspective pp: 72.

12. Pilling D, Boeltzig H (2007) Moving toward e-government: effective strategies for increasing access and use of the internet among non- internet users in the US and UK. Proceedings of the 8th annual international conference on Digital government research: bridging disciplines \& domains, Digital Government Society of North America.

13. Sang S (2009) A Study on the Contribution Factors and Challenges to the Implementation of E-Government in Cambodia. Journal of Software 4: 529-535.

14. Byrne BM (2013) Structural equation modeling with AMOS: Basic concepts, applications, and programming. Routledge.

15. Altameem T (2006) Critical success factors of e-government: A proposed model for e- government implementation. Innovations in Information Technology: IEEE.

16. Sahli N (2009) Survey on e-government approaches: which approach best fits my government? Proceedings of the Second international conference on Global Information Infrastructure Symposium, IEEE Press.

17. Cohen SG, Mankin D (2002) Complex collaborations in the new global economy. Organizational Dynamics 31: 117-133.

18. Ke W, Wei KK (2004) Successful e-government in Singapore. Communications of the ACM 47: 95-99.

19. Pardo TA (2011) E-government interoperability: Interaction of policy, management, and technology dimensions. Social Science Computer Review 61: 206-220.

20. Chircu AM (2008) E-government evaluation: towards a multidimensional framework. Electronic Government, an International Journal 5: 345-363.

21. Rowley J (2011) e-Government stakeholders-Who are they and what do they want? International Journal of Information Management 31: 53-62.

22. Heeks $\mathrm{R}$ (2006) Understanding and measuring e-Government: international benchmarking studies. UNDESA workshop, "EParticipation and E-Government: Understanding the Present and Creating the Future". Budapest, Hungary.

23. Orange $G$ (2006) Care: an integrated framework to support continuous, adaptable, reflective evaluation of e-Government systems: A research note, European and Mediterranean Conference on Information Systems.

24. Pardo TA, Burke GB (2008) Government worth having: A briefing on interoperability for government leaders. Center for Technology in Government, University at Albany, Suny.

25. United Nations (2008) E-government survey 2008 from e-government to connected governance. United Nations, New York.

26. Al-Rashidi H (2013) The role of internal stakeholders and influencing factors during the phases of e-government initiative implementation. Brunel University, School of Information Systems, Computing and Mathematics.

27. Jaeger PT, Thompson KM (2003) E-government around the world: Lessons, challenges, and future directions. Government Information Quarterly 20: 389-394.

28. Soares D, Amaral L (2011) Information systems interoperability in public administration: identifying the major acting forces through a Delphi study. Journal of theoretical and applied electronic commerce research 6: 61-94.

29. Hu PJH, Cui (2006) Examining cross-agency collaborations in egovernment initiatives. System Sciences, 2006. HICSS'06. Proceedings of the 39th Annual Hawaii International Conference on, IEEE.

30. Irani $Z$ (2007) T-government for benefit realisation. Information and management 42: 947-964.

31. Malinauskienè E (2013) Conceptual framework for context-based egovernment interoperability development. Social Technologies: 68-84.

32. Seifert JW, McLoughlin GJ (2007) State e-government strategies: Identifying best practices and applications. DTIC Document.

33. Ndou V (2004) E-government for developing countries: opportunities and challenges. The electronic journal of information systems in developing countries 18 .

34. Prybutok VR (2008) Evaluating leadership, IT quality, and net benefits in an e-government environment. Information \& Management 45: 143-152.

35. Zairi M (1994) Leadership in TQM implementation: some case examples. The TQM Magazine 6: 9-16. 
Citation: Alshetewi S (2016) A Structural Equation Model (SEM) of Governing Factors Influencing the Implementation of t-Government. J Entrepren Organiz Manag 5: 170. doi:10.4172/2169-026X.1000170

Page 7 of 7

36. Karim MA (2003) Technology and improved service delivery: learning points from the Malaysian experience. International Review of Administrative Sciences 69: 191-204.

37. Zhou X (2004) E-Government in China: A Content Analysis of National and Provincial Web Sites. Journal of Computer-Mediated Communication 9: 01.

38. Themistocleous M (2005) Developing e-government integrated infrastructures: A case study. System Sciences HICSS'05. Proceedings of the 38th Annual Hawaii International Conference, IEEE.

39. King S, Cotterill S (2007) Transformational government? The role of information technology in delivering citizen-centric local public services. Local Government Studies 33: 333-354.

40. Eyob E (2004) E-government: breaking the frontiers of inefficiencies in the public sector. Electronic Government, an International Journal 1: 107-114.

41. Gottipati M (2002) Managing e-government portals, Eighth GCC egovernment. Internet \& telecommunications forum.

42. Huang Z, Bwoma PO (2003) An overview of critical issues of egovernment. Issues of Information Systems 4: 164-170.

43. Dos Santos EM, Reinhard N (2011) Electronic government interoperability: Identifying the barriers for frameworks adoption. Social Science Computer Review pp: 0894439310392196.

44. Ramaswamy M (2009) e-Government implementation in transition countries. Handbook of Research on ICT-Enabled Transformational Government pp: 441-451.

45. Scholl HJ, Klischewski R (2007) E-government integration and interoperability: framing the research agenda. International Journal of Public Administration 30: 889-920.

46. Luk SCY (2009) The impact of leadership and stakeholders on the success/failure of e- government service: Using the case study of estamping service in Hong Kong. Government Information Quarterly 26: 594-604.

47. Tripathi R (2013) Effect of organizational factors on interoperability adoption for Indian portals. Transforming Government: People, Process and Policy 7: 285-308.

48. Janssen M, Scholl HJJ (2007) Interoperability for electronic governance. Proceedings of the 1st international conference on Theory and practice of electronic governance, ACM.

49. Bekkers V (2005) The governance of back office integration in egovernment: Some dutch experiences. Electronic Government, Springer pp: $12-25$.
50. Hossan CG (2006) Success and Failure Factors for e-Government projects implementation in developing countries: A study on the perception of government officials of Bangladesh. Poster session presented at the proceedings of 2th European Conference on Mobile Government. Retrieved March, Citeseer.

51. Scholl HJ (2004) Involving salient stakeholders Beyond the technocratic view on change. Action Research 2: 277-304.

52. Janssen M, Cresswell AM (2005) An enterprise application integration methodology for e- government. Journal of Enterprise Information Management 18: 531-547.

53. Kamal M (2011) Analyzing the role of stakeholders in the adoption of technology integration solutions in UK local government: An exploratory study. Government Information Quarterly 28: 200-210.

54. Klischewski R (2011) Architectures for Tinkering?: Contextual Strategies towards Interoperability in E-government. Journal of theoretical and applied electronic commerce research 6: 26-42.

55. Ezz IE, Papazafeiropoulou A (2006) Inter-organisational collaboration towards process integration in the public sector. E-government collaboration in Egypt System Sciences, HICSS'06. Proceedings of the 39th Annual Hawaii International Conference, IEEE.

56. Elliman T (2007) Realising integrated e-government services: a UK local government perspective. Transforming Government: People, Process and Policy 1: 153-173.

57. Weerakkody V (2008) Moving from E-Government to T-Government: A Study of Process Reengineering Challenges in a UK Local Authority Context. International Journal of Electronic Government Research.

58. Klischewski R, Scholl HJ (2006) Information quality as a common ground for key players in e-government integration and interoperability. System Sciences, HICSS'06. Proceedings of the 39th Annual Hawaii International Conference, IEEE.

59. Landsbergen Jr D, Wolken Jr G (2001) Realizing the promise: Government information systems and the fourth generation of information technology. Public administration review 61: 206-220.

60. Ray D (2009) Interoperability and constituents of interoperable systems in public sector. Handbook of Research on ICT-enabled Transformational Government: A Global Perspective, IGI Global, Hershey pp: 175-195. 